\title{
CONSERVATIVE BUSINESS STRATEGY AS MODERATOR OF BOARD INDEPENDENCE AND CORPORATE PERFORMANCE NEXUS IN NIGERIAN FINANCIAL COMPANIES
}

\author{
Henry Osahon \\ Osazevbaru
}

\author{
Senior Lecturer in the Department of Business Administration, Faculty of the \\ Social Sciences, Delta State University, Abraka, Delta State, Nigeria. \\ Email:henryosas@yahoo.com Tel: +2348037786166
}
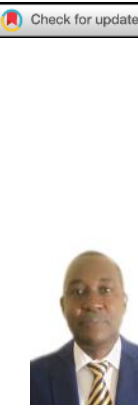

Article History

Received: 21 December 2020 Revised: 15 March 2021 Accepted: 29 April 2021 Published: 27 May 2021

\section{Keywords \\ Governance code \\ Agency theory \\ Stock returns \\ Board cohesion \\ Asymmetric recognition \\ Groupthink \\ Stewardship \\ Expertise.}

JEL Classification: G2 1; G34; L25.

\section{ABSTRACT}

The relationship between board independence and corporate performance is one that is replete with mixed results. This paper analyzes board independence and firm performance in the presence of conservative business strategy. The issues addressed focus on whether board independence contributes meaningfully to performance and whether conservative strategy amplifies the role of board independence in mitigating agency conflict and thus improving firm value or performance. To address this, 312 firm-year observations of firms in the Nigerian financial sector from 2007 to 2018 were analyzed using the ordinary least squares (OLS) regression model, panel data model, and structural equation model (SEM). In the OLS and panel data models, board independence did not show any significant influence on performance. In both models however, conservative strategy was significant. The inclusion of conservative strategy in the model increased the coefficient of determination $\left(\mathrm{R}^{2}\right)$ to $32.1 \%$ and $31 \%$, respectively, for the OLS and panel data models. In the structural equation model, conservative strategy was also significantly related to performance but negatively related to board independence. The evidence from this study shows that conservative business strategy moderates the link between board independence and firm performance. It is therefore recommended that firms should adopt conservative strategy to gain the monitoring and advisory roles of board independence, especially when true independence cannot be guaranteed.

Contribution/Originality: This paper adds to prior literature by investigating the strength of conservative business strategy in the relationship between board independence and firm performance. The application of an analytical framework that enhances the simultaneous analysis of interrelated dependency contributes to the expansion of the methodological scaffold for analyzing institutional characteristics of emerging markets.

\section{INTRODUCTION}

A corporate board as a governance mechanism of a firm has gained importance in recent times because of the need to protect shareholders' resources. The need to align shareholders' interests with that of management means more monitoring and advice for management. Boards provide strategic guidelines to management (Rashid, 2018) and, in the process, carry out oversight functions (Ali, Hanming, \& Ullah, 2018; Arora \& Sharma, 2016). The recognition of a relation between the level of corporate governance in a country and the extent of financial crisis it can absorb has seen most countries institutionalize corporate governance codes (Bawaneh, 2020). Nigeria, as an emerging economy interested in rapid economic growth, has taken steps to build the confidence of both foreign and 
domestic investors by enacting different codes of corporate governance. Specifically, there is the Securities and Exchange Commission (SEC) code, which was revised in 2018 to regulate all listed firms on the Nigerian Stock Exchange. In addition, the Central Bank of Nigeria (CBN) code regulates all financial institutions.

Many works of literature have linked board composition with corporate performance (Borlea, Achim, \& Mare, 2017; Farag \& Mallin, 2017; Garcia-Martin \& Herrero, 2018). Within the scope of a board composition, the issue of board independence is very important. Independent directors are those entrusted by shareholders to represent them and to help reduce problems within an agency. Due to their monitoring role, it is expected that their actions should contribute to firm performance and the maximization of shareholders' wealth. Notwithstanding, empirical evidence presents mixed results on the influence of board independence on performance (Sharifah, Syahrina, \& Julizaerma, 2016). Some studies, such as those by Ponnu \& Karthigeyan (2010); Alshetwi (2017) and Rashid (2018), did not find board independence to have an influence on performance. On the other hand, Makhlouf, Laili, Basah, \& Ramli (2017) and Uribe-Bohorquez, Martínez-Ferrero, \& García-Sánchez (2018) reported that a positive and significant relationship exists. This mixed evidence is suggestive of the need for further investigation into the discourse.

Regarding a negative association between board independence and performance, some studies have suggested that independent directors prefer conservative strategy when trying to protect shareholders' interests (Horváth \& Spirollari, 2012). Conservative business strategy specifies a higher level of verifiability for gains, thereby preventing management from pursuing selfish interests (Boussaid, Hamza, \& Sougne, 2015; Garcia-Lara, Garcia-Osma, \& Penalva, 2016; Han, 2020). Through this connection, agency conflict is minimized and shareholders' wealth is maximized. At times, managers pursue policies that involve taking too much risk. This is especially prevalent where executive compensation is dependent on firm performance. Excessive risk-taking increases the likelihood of bankruptcy. A critical responsibility of the board, therefore, is to bring corporate risk-taking to the optimal point for shareholders. In this regard, it has been shown that independent, external directors are more effective because of their objectivity and conservative outlook (Jiraporn \& Lee, 2018).

Notwithstanding the fact that board independence as a board composition variable in corporate governance has attracted attention in academic and professional discourse, conservative strategy, which complements the primary purpose of board independence, has not been thoroughly investigated. Conservative business strategy enhances the quality of financial information for decision making by both management and investors. Its link with board independence and the joint influence of both conservative strategy and board independence on corporate performance is worth exploring, and this is the gap this study intends to fill. The addition of a business segment variable in this paper, to facilitate an in-depth study of financial services operations, is a point of departure of this study from related studies done on emerging African markets.

Arising from the above, the basic empirical questions are: what is the nature of the relationship between board independence and performance, and does conservative strategy moderate the relationship? These issues are examined from the perspective of an emerging African economy to enable us to relate the results with studies done on developed economies. This study is significant to literature and practice in the following ways. First, it illuminates the agency theory from the perspective of developing economies. Second, it uses a mix of analytical methods, namely OLS, panel data regression and SEM to examine the issues that have been raised. The outcome of this exercise revealed that methodological approaches contribute to conflicting results in the literature. Finally, in terms of practical application and policy implication, the study suggests the application of conservative strategy by firms in order to reinforce the monitoring, advisory and supervisory roles of boards.

\section{LITERATURE REVIEW}

\subsection{Corporate Performance and Board Independence}

In countries where business ownership is dispersed, such as Anglo-Saxon countries, the need for board independence is stronger. Board independence describes the proportion of board members drawn from outside the 
firm who are independent of management. They are also non-executive directors with broad knowledge and expertise to carry out advisory and monitoring roles. By their nature, independent directors are expected to provide independent thinking to mitigate the dangers inherent in "groupthink" (Sharifah et al., 2016). The refinement in corporate governance practices in both Anglo-Saxon and continental model countries have raised the question of whether board independence contributes meaningfully to firm value. The answer to this in the literature is inconclusive.

Some empirical studies have documented that board independence is associated with superior firm performance (Adebayo, Olusola, \& Abiodun, 2013; Joh \& Jung, 2012; Makhlouf et al., 2017; Oyewale, Oloko, \& Olweny, 2016; Zubeltzu-Jaka, Ortas, \& Álvarez-Etxeberria, 2019). These results are consistent with the agency theory that independent directors offer their services without bias and tailor their expertise to shareholders' interests. Again, the quality of the advice offered constitutes invaluable resources, which, according to the resource dependence theory, should improve performance (Aduda, Chogii, \& Magutu, 2013).

There are also studies that have reported a negative association (Alshetwi, 2017; Borlea et al., 2017; GarciaMartin \& Herrero, 2018; Horváth \& Spirollari, 2012; Ponnu \& Karthigeyan, 2010; Rashid, 2018; Wintoki, Linck, \& Netter, 2012). These results align with the stewardship theory that sees insider directors as having more firmspecific expertise and information for superior decision making to enhance firm value. Furthermore, the negative association has also been attributed to methodology employed by the investigator and eagerness on the part of corporations to merely comply with requirements of governance codes by appointing external directors without recognizing that there is an optimal board composition that provides board cohesion. There have also been questions regarding whether these external directors are truly independent or if independence is merely a tag (Alshetwi, 2017; Garcia-Martin \& Herrero, 2018). A third group of empirical results did not find any significant relationship between board independence and performance (Brick \& Chidambaran, 2010; Rodríguez, Alonso, \& Rodríguez, 2013).

Makhlouf et al. (2017) explored the relationship between the effectiveness of boards and the performance of firms. Using the panel data method on data of 120 non-financial listed firms on the Amman Stock Exchange from 2009 to 2013, the study found board independence to positively impact performance measured by return on assets (ROA). In a related study by Bawaneh (2020) on the same market but on 40 financial institutions, the link between independent directors and financial performance was examined with data from 2013 to 2017 . Using the nonparametric Spearman correlation test, the study found no significant connection between board independence and performance measured by ROA and return on equity (ROE). However, a significant positive association was reported for earning per share (EPS) as a performance measure.

Ron, Huang, \& Lu (2018) examined the effects of board independence on the variability of firm performance. To ascertain if there is a causal relationship, information from 2003 NYSE and NASDAQ listing rules pertaining to board independence were generated. The study found that the firms that were non-compliant and had no majority of independent directors experienced a larger decrease in performance variability. In addition, board independence showed negative association with variability in monthly stock return, Tobin's $Q$, accounting accrual and ROA. The study, therefore, concluded that an increase in board independence curtails the powers of the CEO and reduces corporate risk-taking. As firm's decisions are less extreme in the presence of an independent board, there is less variability in performance.

Uribe-Bohorquez et al. (2018) investigated the board independence relationship with corporate performance with institutional factors as moderators. Data for 2185 international firms from 2006 to 2015 were utilized and analysis done using a truncated regression model suitable for panel data. It was found that board independence has a positive impact on performance approximated by technical efficiency. Also, institutional factors exerted a positive moderating effect on the relationship. Alqatan, Chbib, \& Hussainey (2019) also reported a significant positive 
relationship between board independence and Tobin's $Q$ measure of performance using FTSE data of 100 nonfinancial firms from 2012 to 2015.

Koji, Adhikary, \& Tram (2020) traced a negative relationship between board independence and performance in their study of 861 non-family and 551 family firms in Japan using data from 2014 to 2018. For family businesses, the negative relationship was found for ROA as a proxy for performance, while for non-family businesses it was the case of Tobin's Q. Based on the results, the paper concluded that too many independents demonstrated slow communication and decision making.

\subsection{Conservative Business Strategy, Board Independence and Performance}

The lack of conclusive evidence regarding the impact that board independence has on performance perhaps suggests that other variables possibly moderate the relationship. Weir \& Laing (2001) alluded to this by stating that beside board processes, there are other elements that influence the value of independent non-executive directors. Horváth \& Spirollari (2012) suggested conservative strategy. Conservatism is a reporting strategy where there is asymmetric recognition of revenues or gains and losses (Han, 2020). Anticipated gains are deferred and accounted for only when it becomes reasonably certain, while probable losses are immediately recognized (Ho, Li, Tam, \& Zhang, 2015).

The seamless link between conservatism and corporate governance is in the mitigation of agency conflict and encouraging transparent reporting; it also limits managerial opportunism (Ho et al., 2015; Yunos, Ismail, \& Smith, 2012). Conservatism enhances the quality of firms' reports and ultimately the value of the firms as quality information will enhance quality decisions that improve the net present value (NPV) of the firm (Makhlouf et al., 2017). It also helps the board to screen out investments with negative NPV and highly risky positive NPV. Hsieh, Ma, \& Novoselov (2019) submitted that conservative strategy is expedient when business is faced with ambiguity. Han (2020) opined that conservatism as a corporate governance mechanism can alleviate any inherent drawbacks in a firm's business strategy. Yassin, Ali, \& Hamdallah (2015) added that conservative strategy sinks the effect information asymmetry has on stock returns.

Beekes, Pope, \& Young (2004) associated more conservatism with high board independence. Garcia-Lara, Garcia-Osma, \& Penalva (2009); Nasr \& Ntim (2017) also found a positive connection between board independence and conservatism. Therefore, independent directors utilize conservative strategy in their monitoring roles. Oyedokun \& Saad (2018) examined corporate governance effects on conservatism and found a significant positive relationship between board independence and conservatism. A similar result was found by El-Habashy (2019) who investigated corporate governance attributes and their effects on conservatism in Egypt using a sample of the 40 most active non-financial firms from 2009 to 2014; the study reported a significant positive connection between board independence and conservatism.

Amran \& Manaf (2014) reported a negative relationship between board independence and conservatism to conclude that the monitoring role of independents is minor as they lack sufficient information. Enache \& GarciaMeca (2018) found that not all independent directors have equal effectiveness in monitoring. External directors in the category of community influencers were found to contribute to lower earning sensitivity to bad news than those in the categories of business experts and support specialists.

Affes \& Sardouk (2016) reported a positive relationship between conservatism and company performance, and that independent directors effectively moderate the relationship. Jiraporn \& Lee (2018) reported that board independence reduces a firm's total and idiosyncratic risks by $24.87 \%$ and $12.6 \%$, respectively. This submission is consistent with the argument that managers have the tendency for excessive risk-taking. However, with stringent monitoring occasioned by board independence, managers are forced to take significantly fewer risks. The study concluded that board independence causes less risk-taking and is not merely associated with it. A study by Ugwunta \& Ugwuanyi (2019) of Nigerian firms listed in the consumer goods sector found a positive, but not 
significant, effect of conservatism on performance. El-Habashy (2019) found conservatism to have a significant positive impact on corporate performance in Egypt.

Han (2020) considered the joint impact on financial performance of different conservatism measures and business strategy typology. Data of listed firms on the Shanghai and Shenzhen stock markets from 2008 to 2012 were analyzed. It was established that conservatism is a weighty corporate governance mechanism and that conservatism and business strategy jointly influence financial performance positively.

\section{DATA AND METHODS}

This study covers a twelve year period from 2007 to 2018 and focuses on financial firms listed on the Nigeria Stock Exchange (NSE). Complete data on the variables of the study are available for 26 firms and these constitute the sample size. NSE factbooks and companies' annual reports and accounts were the data sources.

\subsection{Variables and Measurement}

The dependent variable is corporate performance approximated by stock returns. Shareholders are more interested in returns as they give an idea of the volatility of the share price and enable evaluation of managerial ability to maximize owners' wellbeing. Firms with riskier strategies have more volatile stock prices than those with conservative strategies. The independent variable is board independence, while the moderating variable is conservative business strategy. To capture firm heterogeneity, control variables were introduced. These variables are firm size, firm leverage and firm business segment. The operational definition of these variables is presented in Table 1.

Table 1. Definition of variables.

\begin{tabular}{l|l}
\hline Variable & Measurement \\
\hline Dependent & $\begin{array}{l}\text { This is proxied by stock returns (STORET) defined as the percentage } \\
\text { change in closing price per share. It is computed as current period } \\
\text { closing price less previous closing price divided by previous closing } \\
\text { price }\left(\left(\mathrm{P}_{\mathrm{t}}-\mathrm{P}_{\mathrm{t}-1}\right) / \mathrm{P}_{\mathrm{t}-1}\right) .\end{array}$ \\
\hline Corporate Performance (CPERF) & $\begin{array}{l}\text { This is the proportion of independent or non-executive directors in the } \\
\text { board. }\end{array}$ \\
\hline Bndependent & $\begin{array}{l}\text { Proxied by market price-to-book value (MPBV) ratio and computed as a } \\
\text { firm's market value divided by its book value or net asset value. }\end{array}$ \\
\hline Moderating & \begin{tabular}{l} 
Approximated by log of total assets. \\
\hline Conservative Business Strategy (CBS)
\end{tabular} \\
\hline Control & $\begin{array}{l}\text { Computed as total debt divided by total assets at year end. } \\
\text { business and zero otherwise. }\end{array}$ \\
\hline Firm Size (FIRSIZ) & \multicolumn{1}{|c|}{ Firm Leverage (FIRLEV) }
\end{tabular}

\subsection{Estimation Model}

The study uses a regression framework with the following models.

$$
\begin{gathered}
\mathrm{CPERF}=\zeta_{0}+\zeta_{1} \mathrm{BINDE}+\zeta_{2} \mathrm{FIRSIZ}+\zeta_{3} \mathrm{FIRLEV}+\zeta_{4} \mathrm{BISEG}+\varepsilon_{\mathrm{t}} \\
\mathrm{CPERF}=\zeta_{0}+\zeta_{1} \mathrm{BINDE}+\zeta_{2} \mathrm{CBS}+\zeta_{3} \mathrm{FIRSIZ}+\zeta_{4} \mathrm{FIRLEV}+\zeta_{5} \mathrm{BISEG}+\varepsilon_{\mathrm{t}}
\end{gathered}
$$

Where:

$\mathrm{CPERF}=$ corporate performance.

BINDE $=$ board independence.

$\mathrm{CBS}=$ conservative business strategy.

FIRSIZ = firm size.

FIRLEV $=$ firm leverage. 
BIZSEG = business segment.

$\zeta_{0}=$ intercept parameter.

$\zeta_{1-5}=$ estimate coefficient parameters.

$\varepsilon_{\mathrm{t}}=$ stochastic term

Model 1 examines the link between corporate performance and board independence with the control variables. Model 2 adds conservatism as a moderating variable to Model 1. If the $\mathrm{R}^{2}$ in Model 2 is higher than $\mathrm{R}^{2}$ in $\mathrm{Model}_{1}$ then conservative strategy amplifies the relationship between performance and board independence. To control for unobservable and time-varying components of firm-level data, a panel data analysis was undertaken using Model 2. Again, to test the interaction effect between the moderator and the outcome and explanatory variables, a structural equation model was implemented.

\section{DATA PRESENTATION}

The analysis of the data begins with descriptive statistics shown in Table 2 to illuminate the data.

Table 2. Descriptive statistics of variables.

\begin{tabular}{c|c|c|c|c|c|c}
\hline Variable/Statistic & STORET & BOIND & CBS & FIRSIZ & FIRLEV & BIZSEG \\
\hline Mean & 0.0916918 & 62.91196 & 1.073077 & 7.899872 & 76.73561 & 0.4230769 \\
\hline Minimum & -0.9349195 & 21.49 & -1.26 & 5.58 & 4.46 & 0 \\
\hline Maximum & 4.576744 & 90.91 & 8.97 & 10.77 & 888.19 & 1 \\
\hline Standard deviation & 0.7106729 & 12.38896 & 1.289895 & 1.036506 & 90.59235 & 0.4948411 \\
\hline Skewness & 3.02406 & -0.0512783 & 2.668719 & 0.244786 & 6.43249 & 0.3113996 \\
\hline Kurtosis & 15.89792 & 2.787507 & 11.61581 & 1.933529 & 49.86829 & 1.09697 \\
\hline No. observations & 312 & 312 & 312 & 312 & 312 & 312 \\
\hline
\end{tabular}

Table 2 shows that the mean of stock returns is 0.0916918. This implies that the average return is $9.17 \%$. The minimum return is -0.9349195 and the maximum is 4.576744 . The standard deviation is 0.7106729 and it shows a wide dispersion of individual values from mean value. Stock return is also positively and highly skewed, as the skewness value of 3.02406 is greater than zero, which is the benchmark. Also, it had leptokurtic distribution as the kurtosis value (15.89792), which is greater than the normal curve value of three. The mean for board independence is 62.91196 . Implicitly, about $62.9 \%$ of board members are non-executive directors. which is quite significant as it is almost two-thirds of board directors. The proportion of non-executive directors ranges from $21.43 \%$ to $90.91 \%$. This wide range is reflected in the standard deviation of 12.38896. It is negatively skewed (-0.0512783) with a kurtosis value of 2.787507 , which is not too far from the normal value of three. However, the distribution is platykurtic.

Conservative business strategy (CBS) has an average value of 1.07307, while firm size and leverage averaged at 7.899872 and 76.73561, respectively. Non-banking businesses tend to be prevalent in the sector as the average value of a business segment is 0.423076 . This value tilts towards zero, which is the score for firms that are not in the banking business. Other symmetrical properties of conservative strategy show asymmetry. For instance, the skewness value of 2.668719 is greater than zero and a kurtosis value of 11.61581 is greater than three. Asymmetry is also true for firm size, firm leverage and business segment, though the skewness value for firm size and business segment are quite close to the normal distribution value. This is evidenced by their relatively low standard deviation value.

\subsection{Correlation Matrix}

This depicts the relationship the variables have among themselves and also sheds light on the issue of multicollinearity. 
Table 3. Correlation Matrix

\begin{tabular}{c|c|c|c|c|c|c}
\hline Variable & STORET & BOIND & CBS & FIRSIZ & FIRLEV & BIZSEG \\
\hline STORET & 1.0000 & & & & & \\
\hline BOIND & -0.0101 & 1.0000 & & & & \\
\hline CBS & 0.5631 & -0.0396 & 1.0000 & & & \\
\hline FIRSIZ & 0.0519 & -0.2351 & 0.0556 & 1.0000 & & \\
\hline FIRLEV & -0.0528 & -0.1310 & -0.1751 & -0.0979 & 1.0000 & \\
\hline BIZSEG & 0.1047 & -0.2943 & 0.1372 & 0.8936 & 0.0951 & 1.0000 \\
\hline
\end{tabular}

The correlation between variables is presented in Table 3, and shows that board independence (-0.0101) and firm leverage (-0.0528) have a negative correlation with stock returns. The other variables (conservative strategy, firm size and business segment) have a positive correlation with stock returns

\subsection{Variance Inflation Factor (VIF) Test}

This test enables the determination of the presence or otherwise of multicollinearity among the explanatory variables. From Table 4, the mean VIF is 3.32 and is less than the benchmark value of ten. This indicates the absence of multicollinearity and means that the variables are suitable for multiple regression.

Table 4. VIF test.

\begin{tabular}{c|c|c}
\hline Variable & VIF & $\mathbf{1} /$ VIF \\
\hline BOIND & 1.11 & 0.902008 \\
\hline CBS & 1.13 & 0.883537 \\
\hline FIRSIZ & 6.38 & 0.156793 \\
\hline FIRLEV & 1.33 & 0.754246 \\
\hline BIZSEG & 6.64 & 0.150646 \\
\hline Mean VIF & 3.32 & \\
\hline
\end{tabular}

\subsection{Empirical Analysis}

The results of the implementation of the estimation models are presented in Table 5.

Table 5. Empirical results.

\begin{tabular}{|c|c|c|c|}
\hline $\begin{array}{l}\text { Model } \\
\text { Result }\end{array}$ & OLS Result (for Model 1) & OLS Result (for Model 2) & $\begin{array}{c}\text { Panel Fixed Effect Model } \\
\text { Result (for Model 2) }\end{array}$ \\
\hline Variable & Coefficient (Probability) & Coefficient (Probability) & Coefficient (Probability) \\
\hline Const & $1.57355(0.029)$ & $-0.52923(0.401)$ & $0.630563(0.303)$ \\
\hline BOIND & $0.00108(0.750)$ & $0.00157(0.582)$ & $-0.00091(0.721)$ \\
\hline CBS & & $0.31475(0.000)^{* * * *}$ & $0.23584(0.000)^{* * * *}$ \\
\hline FIRSIZ & $-0.21828(0.021)^{* *}$ & $0.01896(0.816)$ & $-0.10433(0.183)$ \\
\hline FIRLEV & $-0.00094(0.054)$ & $0.00041(0.329)$ & $-0.00026(0.507)$ \\
\hline BIZSEG & $0.58327(0.004)^{* * * *}$ & $0.00655(0.970)$ & $0.25900(0.109)$ \\
\hline $\mathrm{R}^{2}$ & 0.0322 & 0.3205 & 0.3086 \\
\hline $\mathrm{F}$-value & $2.55(0.039)^{* * *}$ & $28.97(0.000)^{* * * *}$ & $10.98(0.0000)^{* * * *}$ \\
\hline
\end{tabular}

The OLS result for Model 1 shows that board independence is positive but does not significantly contribute to performance. Firm size has a significant negative influence on performance, while business segment positively and significantly influences performance. This means that there is a difference in performance arising from operating in the core banking business or operating in the non-banking business. This model is well fitted judging from the Fvalue, which is significant at $5 \%$.

In the OLS Model 2, which seeks to measure the influence of conservative strategy, the estimate for this variable is positive and significant at $1 \%$. Thus, conservative strategy contributes to improving performance. Again, the model fit is significant at $1 \%$ based on the $\mathrm{F}$-value. The OLS result for Model 2 shows an $\mathrm{R}^{2}$ value of 0.3205 
compared to the corresponding value of 0.0322 in Model 1. This goes to show that conservatism raised the explanatory power of the model to $32.05 \%$ against $3.22 \%$ where conservatism was not captured. Though board independence and other variables are positive, they do not significantly increase performance in the presence of conservative strategy.

The result in the third column of Table 5 is the panel data regression result. This was undertaken to illuminate firm-specific characteristics that might be embedded in the data and provide in-depth analysis of different drivers of corporate performance. The result presented is for the fixed effects model. To arrive at this decision, the Hausman test was implemented and the probability value was statistically significant at $1 \%$ suggesting that a fixed effects model is more appropriate (Shukla, Sivasankaran, \& Dasgupta, 2018). In this model, board independence, firm size and firm leverage are negatively related to performance but are not significant, while business segment, though positive, is also not significant. Conservative business strategy, at 0.23584 , is statistically significant at $1 \%$ and positive, which indicates that this variable influences corporate performance.

To investigate the interaction effect or the structural relationship between conservative business strategy and the dependent, independent and control variables, the study implemented a structural equation model (SEM). In one analysis, the SEM estimated multiple dependence and interrelated dependence. However, this simultaneous analysis requires the stability condition to be satisfied. The SEM results satisfy the stability condition as all the eigenvalues are within the unit circle. The total effect results are shown in Table 6, while the structural path analysis is shown in the appendix.

Table 6. SEM total effect result.

\begin{tabular}{c|c|c|c}
\hline Structural Path & Coefficient & $\mathbf{z}$ & Probability \\
\hline BOIND <- CBS & -0.3801218 & -0.70 & 0.484 \\
\hline FSIZE <- CBS & 0.044663 & 0.98 & 0.325 \\
\hline FLEV <- CBS & -12.29593 & -3.14 & $0.002^{* * *}$ \\
\hline BIZSEG <- CBS & 0.0526501 & 2.45 & $0.014^{*} *$ \\
\hline STORET <- CBS & 0.31023 & 12.04 & $0.000 * * *$ \\
\hline Note: ** and *** denote significance at $5 \%$ and $1 \%$, respectively.
\end{tabular}

From Table 6, we can see that the interaction between board independence and conservative strategy is negative. This negative value shows that more independent directors in a firm will reduce the need for CBS to tone down opportunistic behavior of management. However, this interaction is not significant statistically. CBS has a positive structural interaction with firm size (0.044663), suggesting that large firms have more need for CBS. Again, this interaction is insignificant. On the contrary, CBS interactions with leverage and business segment are significant at $1 \%$ and $5 \%$, respectively. Its interaction with performance measured by stock returns is positive (0.31023) and statistically significant at $1 \%$. On the basis of the empirical results, the study submits; first, that board independence has no significant relationship with performance but the sign of the parameter estimate is sensitive to the analysis technique used; and second, that conservative strategy significantly moderates the relation between board independence and firm performance. The first submission is among others consistent with Brick \& Chidambaran (2010); Rodríguez et al. (2013) and Ron et al. (2018), while the second concurs with Yassin et al. (2015); Affes \& Sardouk (2016) and Han (2020).

\section{CONCLUSION}

This paper has examined corporate board independence and firm performance. This is against the backdrop of agency and resource dependence theories that see independent boards as having the ability to objectively monitor and advise management to avoid managerial opportunism and increase firm value. This study deepens the investigation by adding CBS as a moderator of board independence and performance relationship. Conservatism as a corporate governance mechanism recommends a cautious approach to revenue recognition to enhance quality of 
information for managerial decision-making. The outcome of the investigation shows that board independence is positive in the OLS model and negative in the panel model but not significant in influencing firm performance.

The analysis of the interrelatedness of the moderator variable with board independence shows that a truly independent board will reduce the need for conservatism. Put differently, more conservatism will diminish the need for board independence. CBS was also found to increase the coefficient of determination of the estimated models by approximately $31 \%$ to $32 \%$. This study found that the mixed results in empirical literature is due to the methodologies adopted; while board independence was positive in the OLS model, it was negative in the panel model and SEM. Based on the findings, it is recommended that firms that do not have truly independent boards should adopt CBS to improve performance. Also recommended is that firms should compose their independent boards by appointing those who have expertise in the firm's business segment.

This study is not without limitations. It has used only one measure of performance - stock returns. It has also used data from only one economic activity sector of the NSE. Further studies should adopt a mix of firm performance proxies and data from other economic sectors.

Funding: This study received no specific financial support.

Competing Interests: The author declares that there are no conflicts of interests regarding the publication of this paper.

\section{REFERENCES}

Adebayo, O., Olusola, A. G., \& Abiodun, O. F. (2013). Relationship between corporate governance and organizational performance: Nigerian listed organizations experience. International Journal of Business and Management Invention, $2(9), 1-6$.

Aduda, J., Chogii, R., \& Magutu, P. O. (2013). An empirical test of competing corporate governance theories on the performance of firms listed at the Nairobi Securities Exchange. European Scientific Journal, 9(13).Available at: 33-48.

Affes, H., \& Sardouk, H. (2016). Accounting conservatism and corporate performance: The moderating effect of the board of directors. Journal of Business and Financial Affairs, 5(2),187-195.

Ali, Z., Hanming, Y., \& Ullah, A. (2018). Corporate governance and dividend smoothing: Evidence from Pakistani listed banks. Asian Journal of Business and Accounting, 11(2),85-120.Available at: https://doi.org/10.22452/ajba.vol1 1 no2.3.

Alqatan, D., Chbib, I., \& Hussainey, K. (2019). How does board structure impact on firm performance in the UK? Corporate Board: Role, Duties $\mathfrak{E}^{2}$ Composition, 15(2),18-27.Available at: https://doi.org/10.22495/cbv15i2art2.

Alshetwi, M. (2017). The association between board size, independence and firm performance: Evidence from Saudi Arabia. Global Journal of Management And Business Research, 17(1),16-28.

Amran, N. A., \& Manaf, K. B. A. (2014). Board independence and accounting conservatism in Malaysian companies. ProcediaSocial and Behavioral Sciences, 164,403-408.Available at: https://doi.org/10.1016/j.sbspro.2014.11.095.

Arora, A., \& Sharma, C. (2016). Corporate governance and firm performance in developing countries: Evidence from India. Corporate Governance, 16(2),420-436.

Bawaneh, S. S. (2020). Impact of corporate governance on financial institutions? Performance: A board composition case. Asian Economic and Financial Review, 10(1),54-63.

Beekes, W., Pope, P., \& Young, S. (2004). The link between earnings timeliness, earnings conservatism and board composition: Evidence from the UK. Corporate Governance: An International Review, 12(1),47-59.Available at: https://doi.org/10.1111/j.1467-8683.2004.00342.x.

Borlea, S. N., Achim, M. V., \& Mare, C. (2017). Board characteristics and firm performances in emerging economies. Economic Research, $30(1), 55-75$.

Boussaid, N., Hamza, T., \& Sougne, D. (2015). Corporate board attributes and conditional accounting conservatism: Evidence from French firms. Journal of Applied Business Research (JABR), 31(3),871-890.Available at: https://doi.org/10.19030/jabr.v31i3.9224. 
Brick, I. E., \& Chidambaran, N. (2010). Board meetings, committee structure, and firm value. Journal of Corporate Finance, $16(4), 533-553$.

El-Habashy, H. (2019). The impact of accounting conservatism on corporate performance indicators in Egypt. International Journal of Business Management, 14(1),1-11.

El-Habashy, H. A. (2019). The effect of corporate governance attributes on accounting conservatism in Egypt. Academy of Accounting and Financial Studies Journal, 23(3),1-18.

Enache, L., \& Garcia-Meca, E. (2018). Board composition and accounting conservatism: The role of business experts, support specialists and community influential. Australian Accounting Reviere, 29(1),20-48.

Farag, H., \& Mallin, C. (2017). Monitoring corporate boards: Evidence from China. European Journal of Finance, 25(6),524-549.

Garcia-Lara, J. M., Garcia-Osma, B., \& Penalva, F. (2009). Accounting conservatism and corporate governance. Review of Accounting Studies, 14(1),161-201.

Garcia-Lara, J. M., Garcia-Osma, B., \& Penalva, F. (2016). Accounting conservatism and firm investment efficiency. Journal of Accounting and Economics, 61(1),221-238.

Garcia-Martin.., C. J., \& Herrero, B. (2018). Board of directors: Composition and effect on the performance of the firm. Economic Research, 31(1),1015-1041.

Han, L. (2020). Business strategy, accounting conservatism and performance. Accounting and Finance Research, 9(2),23-34.

Ho, S. S., Li, A. Y., Tam, K., \& Zhang, F. (2015). CEO gender, ethical leadership, and accounting conservatism. Journal of Business Ethics, 127(2),351-370.

Horváth, R., \& Spirollari, P. (2012). Do the board of directors' characteristics influence firm's performance? The US evidence. Prague Economic Papers, 4(1),470-486.

Hsieh, C.-C., Ma, Z., \& Novoselov, K. E. (2019). Accounting conservatism, business strategy, and ambiguity. Accounting, Organizations and Society, 74,41-55.Available at: https://doi.org/10.1016/j.aos.2018.08.001.

Jiraporn, P., \& Lee, S. M. (2018). How do independent directors influence corporate risk-taking? Evidence from a quasi-natural experiment. International Review of Finance, 18(3),507-519.Available at: https://doi.org/10.1111/irfi.12144.

Joh, S. W., \& Jung, J. Y. (2012). The effects of outside board on firm value in the emerging market from the perspective of information transaction costs. Asia-Pacific Journal of Financial Studies, 41(2), 175-193.

Koji, K., Adhikary, B. K., \& Tram, L. (2020). Corporate governance and firm performance: A comparative analysis between listed family and non- family firms in Japan. Journal of Risk and Financial Management, 13(9),215-235.Available at: https://doi.org/10.3390/jrfm13090215.

Makhlouf, M. H., Laili, N. H., Basah, M. Y., \& Ramli, N. (2017). Board of director's effectiveness and firm performance. Research Journal of Finance and Accounting, 8(18),76-88.

Nasr, M., \& Ntim, C. G. (2017). Corporate governance mechanism and accounting conservatism: Evidence from Egypt. Corporate Governance, 17(1),132-164.

Oyedokun, G. E., \& Saad, S. (2018). Corporate governance and accounting conservatism in Nigerian foods and beverages firms. American Journal of Economics, Finance and Management, 4(4),124-133.

Oyewale, I. O., Oloko, M. A., \& Olweny, T. (2016). The relationship between board independence and financial performance of listed manufacturing companies. European Journal of Business, Economics and Accountancy, 4(9),65-80.

Ponnu, C., \& Karthigeyan, R. (2010). Board independence and corporate performance: Evidence from Malaysia. African Journal of Business Management, 4(6),858-868.

Rashid, A. (2018). Board independence and firm performance: Evidence from Bangladesh. Future Business Journal, 4(1),3449.Available at: https://doi.org/10.1016/j.fbj.2017.11.003.

Rodríguez, F. M., Alonso, S. F., \& Rodríguez, J. R. (2013). Structure of the board of directors and performance of the listed Spanish company. European Journal of Business Management and Economics, 22(3),155-168. 
Ron, B., Huang, P., \& Lu, Y. (2018). Board independence and the variability of firm performance: Evidence from an exogenous regulatory shock. Australian Journal of Management, 43(1),3-26.Available at: https://doi.org/10.1177/0312896217708227.

Sharifah, F., Syahrina, A. H., \& Julizaerma, M. K. (2016). Board independence and firm performance. Procedia Economics and Finance, 37,460-465.

Shukla, A., Sivasankaran, N., \& Dasgupta, S. A. (2018). Do board characteristics impact the market performance of Indian banks.

Asian Economic and Financial Review, 8(11),1365-1383.Available at:
https://doi.org/10.18488/journal.aefr.2018.811.1365.1383.

Ugwunta, D. O., \& Ugwuanyi, B. U. (2019). Accounting conservatism and performance of nigerian consumer goods firms: an examination of the role of accruals. International Journal of Financial Research, 10(1),1-9.Available at: https://doi.org/10.5430/ijfr.v10n1p1.

Uribe-Bohorquez, M.-V., Martínez-Ferrero, J., \& García-Sánchez, I.-M. (2018). Board independence and firm performance: The moderating effect of institutional context. Journal of Business Research, 88,28-43.Available at: https://doi.org/10.1016/j.jbusres.2018.03.005.

Weir, C., \& Laing, D. (2001). Governance structures, director independence and corporate performance in the U.K. European Business Review, 13(2),86-95.

Wintoki, M. B., Linck, J. S., \& Netter, J. M. (2012). Endogeneity and the dynamics of internal corporate governance. Journal of Financial Economics, 105(1),581-606.

Yassin, M., Ali, Y., \& Hamdallah, M. (2015). The relationship between information asymmetry and stock returns in the presence of accounting conservatism. International Journal of Business and Management, 10(5),126-133.

Yunos, R., Ismail, Z., \& Smith, M. (2012). Ethnicity and accounting conservatism: Malaysian evidence. Asian Review of Accounting, 20(1),34-57.

Zubeltzu-Jaka, E., Ortas, E., \& Álvarez-Etxeberria, I. (2019). Independent directors and organizational performance: New evidence from a meta-analytic regression analysis. Sustainability, 11(24),7121.Available at: https://doi.org/10.3390/su1 1247121 .

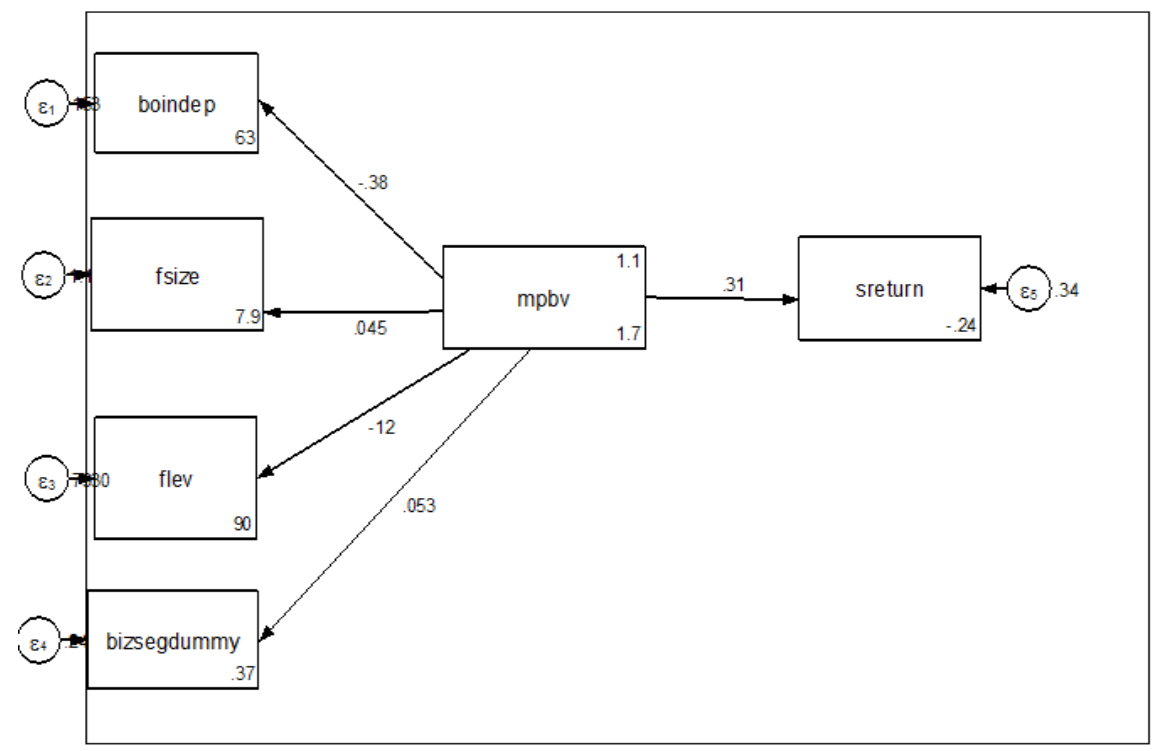

Appendix 1. SEM Path Result.

Views and opinions expressed in this article are the views and opinions of the author(s), Asian Economic and Financial Review shall not be responsible or answerable for any loss, damage or liability etc. caused in relation to/arising out of the use of the content. 